\title{
Characterization, Phylogeny, and Genome Analyses of Nonpathogenic Xanthomonas campestris Strains Isolated from Brassica Seeds
}

\author{
Yung-An Lee, ${ }^{\dagger}$ Pei-Yu Yang, and Shau-Chang Huang \\ Department of Life Science, Fu Jen Catholic University, Xin-Zhuang District, New Taipei City, Taiwan, Republic of China \\ Accepted for publication 2 February 2020.
}

ABSTRACT

\begin{abstract}
Xanthomonads were detected by using the Xan-D(CCF) medium from the brassica seeds, and their pathogenicity was determined by plant inoculation tests. It was found that some seed lots were infested with Xanthomonas campestris pv. campestris, some with X. campestris pv. raphani, and some with nonpathogenic xanthomonads. The nonpathogenic xanthomonad strains were identified as $X$. campestris, and the multilocus sequence analysis showed that the nonpathogenic $X$. campestris strains were grouped together with pathogenic $X$. campestris, but not with nonpathogenic strains of $X$. arboricola. In addition, all isolated $X$. campestris pv. campestris and $X$. campestris pv. raphani strains were positive in the $h r p F$-PCR, but the nonpathogenic strains were negative. It was further found that nonpathogenic $X$. campestris strain $\mathrm{nE} 1$ does not contain the entire pathogenicity island ( $h r p$ gene cluster; type III secretion system) and all type III effector protein genes based on the whole genome sequence analyses. The
\end{abstract}

nonpathogenic $X$. campestris strain $\mathrm{nE} 1$ could acquire the entire pathogenicity island from the endemic $X$. campestris pv. campestris and $X$. campestris pv. raphani strains by conjugation, but type III effector genes were not cotransferred. The studies showed that the nonpathogenic $X$. campestris strains indeed exist on the brassica seeds, but it could be differentiated by the PCR assays on the hrp and type III effector genes. Nevertheless, the nonpathogenic X. campestris strains cannot be ignored because they may be potential gene resources to increase genetic diversity in the endemic pathogenic $X$. campestris pv. campestris and $X$. campestris pv. raphani strains.

Keywords: bacteriology, disease control and pest management, pathogenicity island, plant seed detection, type III secretion system, type III effector, Xanthomonas campestris
The plant pathogenic bacterium Xanthomonas campestris pv. campestris is a seedborne bacterium that causes black rot of crucifers. Contaminated plant seeds are an important primary source of inoculum for the bacteria (Roberts et al. 1999), and the use of pathogen-free seeds is critical to control the bacterial disease. Seed assays to detect $X$. campestris pv. campestris are therefore routinely performed in many laboratories. Some semiselective media are recommended in Working Sheets in the ISTA Handbook on Seed Health Testing (Schaad and Franken 1996), but several yellow non-xanthomonads associated with plant tissues could still grow on the media and interfere with the detection and identification. An xanthomonad differential medium (Xan-D medium) was previously developed to differentiate xanthomonads from yellow nonxanthomonads and is successfully used to isolate the viable xanthomonads from naturally diseased cabbages and infested cabbage seeds (Lee et al. 2009).

The pathogenic xanthomonads of cruciferous vegetables include not only $X$. campestris pv. campestris (black rot pathogen) but also $X$. campestris pv. raphani (leaf spot pathogen) (Fargier and Manceau 2007). In addition, there is growing evidence that many nonpathogenic (or commensal) xanthomonads could exist on plant surfaces or seeds and cause no disease symptoms on the host from which they were isolated (Vauterin et al. 1996). The nonpathogenic xanthomonads have been reported to occur on rice seeds (Ming et al. 1991). Because the detection of $X$. campestris pv. campestris or $X$. campestris pv. raphani on cruciferous vegetable seeds, such as cabbage and cauliflower, is an important plant quarantine measure

${ }^{\dagger}$ Corresponding author: Y.-A. Lee; 035545@mail.fju.edu.tw

Funding: This research was supported by grants from the Council of Agriculture (102AS-10.2.5-BQ-B2), Taiwan, Republic of China.

The author(s) declare no conflict of interest.

(c) 2020 The American Phytopathological Society for the management of diseases, the existence of nonpathogenic xanthomonads on the seed lots may complicate plant quarantine and disease treatment.

The developed semiselective media for xanthomonads could not differentiate the pathogenic and nonpathogenic, and the pathogenicity of xanthomonads should be further determined by timeconsuming plant inoculation tests. In practical diagnosis, it is important to identify the nonpathogenic in a rapid manner. The hrp (hypersensitive response and pathogenicity) genes, coding for the type III secretion system (T3SS), have been used to identify pathogenic and nonpathogenic $X$. campestris pv. vesicatoria (Leite et al. 1994). Among $h r p$ genes, $h r p F$ was reported to contribute to pathogenicity and/or virulence of pathogenic xanthomonads and was used to develop a PCR-based detection method of $X$. campestris pv. campestris (Berg et al. 2005; Park et al. 2004). It was also found that some $X$. campestris pv. campestris strains isolated from cruciferous horseradish failed to amplify any DNA products using $h r p F$ primers and also did not develop infection on plant hosts (Berg et al. 2005).

In this paper, we determined the identity of $X$. campestris strains isolated from the brassica seeds and report that nonpathogenic $X$. campestris strains that are free of T3SS indeed exist on the seeds. The multilocus sequence analysis was further used to determine the phylogenetic relationship between the isolated nonpathogenic $X$. campestris strains and the previously identified nonpathogenic $X$. campestris and $X$. arboricola strains (Fargier et al. 2011; Garita-Cambronero et al. 2017), which provides useful information about the emergence and distinction of pathogenic strains of $X$. campestris. The occurrence of nonpathogenic $X$. campestris on the cruciferous seeds may challenge the current seed detection methods of $X$. campestris pv. campestris and $X$. campestris pv. raphani, and also raise the question of what genes the nonpathogenic $X$. campestris lacks regarding the pathogenicity, and whether the gene transfer might occur between the nonpathogenic and pathogenic $X$. campestris. Whole genome analysis was used to compare the nonpathogenic with pathogenic 
$X$. campestris, especially focusing on the genes of pathogenicity, and the possibility of gene transfer between them was also determined. This study further provides some genetic markers to differentiate nonpathogenic and pathogenic X. campestris after isolation from brassica seeds.

\section{MATERIALS AND METHODS}

Isolation and characterization of xanthomonads isolated from brassica seeds. The brassica seeds were assayed for xanthomonads using a seed-wash dilution plating assay. Briefly, $3 \mathrm{~g}$ of seeds per seed lot was incubated in $10 \mathrm{ml}$ of washing buffer $(0.85 \% \mathrm{NaCl} ; 0.02 \%$ Tween 80$)$ in a $120-\mathrm{ml}$ flask. The flasks were placed on a rotary shaker $(125 \mathrm{rpm})$ at $28^{\circ} \mathrm{C}$ for $5 \mathrm{~h}$. The seed wash was serially diluted tenfold. Then $100 \mu$ of each dilution was plated onto the plates of Xan-D(CCF) medium (Lee et al. 2009) and spread over the surface with a sterile bent glass rod. An additional $1 \mathrm{ml}$ of seed wash was centrifuged at $13,000 \times g$ for $1 \mathrm{~min}$ and a $900-\mu \mathrm{l}$ supernatant was removed. The resulting pellet was resuspended in $100 \mu \mathrm{l}$ of the remaining water buffer and spread onto the plates of Xan-D(CCF) medium. Plates were incubated at $28^{\circ} \mathrm{C}$ and observed for the presence of typical colonies (wet-shining yellow-green with milky and clear zones) of xanthomonad for 3 to 5 days.

Some seed lots were contaminated with Stenotrophomonas spp., such as $S$. maltophilia, whose colony is also yellow-green, but nonmucoid and raised with undulate margin on the Xan-D(CCF) medium (Lee et al. 2009). The colonies were then subcultured to the YDC medium (1\% yeast extract, $2 \%$ dextrose, $2 \% \mathrm{CaCO}_{3}$, and $1.5 \%$ Bacto-agar) (Wilson et al. 1967) and tested by estA-PCR using the Xc-lip-F2/Xc-lip-R2 primer set (Lee et al. 2009). Xanthomonads are yellow and mucoid and positive in the estA-PCR, but Stenotrophomonas spp. are pale or light yellow and flat on the YDC medium and negative in the PCR.

Pathogenicity test. The pathogenicity of the isolated xanthomonads was tested by inoculating cabbage seedlings (Brassica oleracea L. var. capitata) by cutting leaf margins with a pair of sterilized scissors that had been dipped in a suspension of bacteria containing $10^{6}$ to $10^{7} \mathrm{CFU} / \mathrm{ml}$. The seedlings were also inoculated by dusting Carborundum on the leaves and then rubbing leaves with the bacterial suspension $\left(10^{6}\right.$ to $\left.10^{7} \mathrm{CFU} / \mathrm{ml}\right)$. The inoculated plants were covered with a plastic bag in a growth camber at $26^{\circ} \mathrm{C}$ under conditions of $16 \mathrm{~h}$ of light and $8 \mathrm{~h}$ of darkness. After $24 \mathrm{~h}$, the plastic bag was removed and plants were maintained in the growth chamber and symptoms were evaluated after 7 to 14 days.

Phylogenetic analysis of isolated nonpathogenic xanthomonads. The isolated xanthomonads that did not cause any symptoms on cabbage were considered nonpathogenic xanthomonads. To further determine their identity and phylogenetic relationship with pathogenic $X$. campestris pv. campestris and $X$. campestris pv. raphani, the colonies were subjected to PCR assays to obtain their partial 16S rRNA and gyrB gene fragments using 16S-Fm (5'-AGTT TGATCCTGGCTCAGAGTGAA-3')/16S-R4 (5'-GCACCTTCCGA TACGGCTACCTTG-3') and Xgyr-PCR2F/Xgyr-rsp1 (Parkinson et al. 2007) as primer sets, which yield about 1,520- and 730-bp DNA fragments, respectively. The DNA fragments were ligated into pGEM-T Easy vectors (Promega Corp., Madison, WI), and double-stranded DNA sequencing was performed with standard universal T7 and SP6 primers. The 16S rRNA sequences were analyzed using sequence analysis tools and the database of the National Center for Biotechnology Information (NCBI). The nucleotide sequence of $g y r B$ was trimmed in silico at positions corresponding to the 5'-end ATCACCGGCG and 3 '-end GAGCAGTTGTG to generate 530-bp long sequences (Parkinson et al. 2007), and multiple sequence alignments were performed using ClustalW (Thompson et al. 1994) with the trimmed sequences of other xanthomonads from GenBank. The phylogenetic tree was inferred by the neighbor-joining method (Saitou and Nei 1987) by using a MEGA4 program (Tamura et al. 2007).
The multilocus sequence analysis (MLSA) of four housekeeping genes, dnaK (heat shock protein 70, molecular chaperone DnaK), fyuA (TonB-dependent receptor), gyrB (DNA gyrase subunit B), and $r p o D$ (RNA polymerase sigma-70 factor), was further used to analyze the phylogenetic relationship between the isolated nonpathogenic $X$. campestris strains, $\mathrm{nE} 1$ and $\mathrm{nT} 1$, and other nonpathogenic and pathogenic $X$. campestris strains from brassica crops (Fargier et al. 2011). The MLSA also included the nonpathogenic (T3SS-negative) and pathogenic $X$. arboricola strains isolated from Prunus (Garita-Cambronero et al. 2017) in order to understand the association between nonpathogenic xanthomonads and their plant hosts. The partial sequences of four genes of $X$. arboricola strains are obtained from GenBank based on their accession numbers indicated in Garita-Cambronero et al. (2017). The gene sequences of $X$. campestris pv. campestris strain ATCC 33913 (NC_003902.1), X. campestris pv. raphani 756C (NC_017271.1), X. campestris pv. incanae CFBP 2527R (NZ_ CM002636.1), and X. campestris pv. barbareae CFBP $582 \overline{5}$ (nonpathogenic; NZ_CM002638.1) were obtained from their genome sequences in the NCBI database. The sequences of the isolated nonpathogenic $X$. campestris strain $\mathrm{nE1}$ are from the assembled contigs after whole genome sequencing as described below and those of nonpathogenic X. campestris strain nT1 were obtained by sequencing the PCR products as described in Young et al. (2008). Each sequence of four housekeeping genes was trimmed to the following size: dnaK, 842 positions; fyuA, 601 positions; gyrB, 631 positions; and $r p o D, 759$ positions, and sequences were concatenated to give a total length of 2,833 positions according to Garita-Cambronero et al. (2017). Multiple alignments of the concatenated nucleotide sequences and the construction of phylogenetic trees were performed as described above.

Draft genome analysis of a nonpathogenic Xanthomonas sp. strain. The genome of nonpathogenic $X$. campestris strain $\mathrm{nE} 1$ was sequenced with $2 \times 300$-bp paired-end sequencing of a shotgun library on an Illumina MiSeq system. After quality trimming of the raw sequencing reads and assembly of the trimmed sequencing reads into contigs, the assembled contigs of strain $\mathrm{nE1}$ were compared with the genome sequences of $X$. campestris pv. campestris ATCC 33913 (accession number NC_003902) and $X$. campestris pv. raphani $756 \mathrm{C}$ (accession number CP002789) using DNASTAR Lasergene 12.1 (DNASTAR, Inc., Madison, WI) to determine the existence of type-III secretion system encoded by the hrp gene cluster (pathogenicity island) and type III effector genes. Because most of type III effector genes are distributed in different genomic regions, the nucleotide sequence of each type III effector gene currently identified in $X$. campestris pv. campestris and $X$. campestris pv. raphani (Ryan et al. 2011) was used to search for the homolog in the assembled contigs. In addition, two transcriptional activators of hrp genes, $h r p G$ and $h r p X$, located outside the pathogenicity island, were also searched.

Conjugation between pathogenic and nonpathogenic $X$. campestris strains. To determine whether the pathogenicity island can be transferred by conjugation from the endemic Xcc1-1 and Xcr-R1 strains to the nonpathogenic X. campestris strain nE1. A selection marker, tetracycline resistance gene $\left(\mathrm{Tc}^{\mathrm{R}}\right)$, was first inserted into the $h r p F$ of pathogenicity island in Xcc1-1 and Xcr-R1 strains by transposon mutagenesis and marker exchange. A partial $h r p F$ DNA fragment (1,906 bp) was amplified from the Xcc1-1 strain by a PCR assay using hrpF-2-F/hrpF-2-R as primers and ligated into pGEM-T Easy vectors (Promega Corp.). The pGEM-Teasy- $h r p F$ was subjected to mutagenesis with EZ::Tn5 $5^{\mathrm{TM}}$ $<$ TET-1 > transposon insertion kit (EPICENTRE Biotechnologies, Madison, WI) according to the directions of the manufacturer. A plasmid with a transposon inside $h r p F$ was selected and designated as pGEM-Teasy-hrpF::Tn5<TET-1>. The plasmid was further introduced into endemic Xcc1-1 and Xcr-R1 strains, which were isolated from diseased cabbage and radish more than 15 years ago, 
by electroporation (Yang et al. 1991). Double recombinant clones, called Xcc1-1 ( $h r p F::$ Tn5<TET-1>) and Xcr-R1 ( $r r p F:: T n 5<$ TET-1>), were selected on the basis of resistance to tetracycline and further verified by the hrpF-2 PCR assay.

Strains Xcc1-1 (hrpF::Tn5<TET-1>) and Xcr-R1 (hrpF:: Tn5<TET-1>), which contain the tetracycline resistance gene in the $h r p F$ of pathogenicity island, were used as donor bacteria, and the $\mathrm{nE} 1$ rifampicin-resistant $\left(\mathrm{Rif}^{\mathrm{R}}\right)$ strain as a recipient bacterium in the conjugation test. Both donor and recipient bacteria were grown overnight at $28^{\circ} \mathrm{C}$ on Luria Bertani (LB) agar medium (Miller 1972) containing tetracycline $(12.5 \mu \mathrm{g} / \mathrm{ml})$ or rifampicin $(75 \mu \mathrm{g} / \mathrm{ml})$. Bacteria were collected from solid media and cultured again in LB broth without antibiotics for $6 \mathrm{~h}$. Equal volume $(750 \mu \mathrm{l})$ of donor and recipient bacteria were mixed in a tube and centrifuged briefly (approximately $30 \mathrm{~s}$ ), and the supernatant was discarded. The bacterial pellets were suspended in $50 \mu \mathrm{l}$ of sterile tap water by pipetting, plated on the nutrient yeast extract-glycerol agar (NYGA; $0.5 \%$ Bacto-peptone, $0.3 \%$ yeast extract, $2 \%$ glycerol, and $1.2 \%$ Bacto-agar) (Daniels et al. 1984), and incubated at $28^{\circ} \mathrm{C}$ for 16 to 24 h. The bacteria were scraped from the NYGA plates, suspended in 50 to $100 \mu$ l of sterile tap water and spread onto the LB agar medium with tetracycline and rifampicin at $28^{\circ} \mathrm{C}$ for 3 to 14 days. The putative transconjugant colonies growing on the medium were selected and determined by the PCR assay using (i) the Tc-F/Tc-R primer set for the tetracycline resistance gene of Tn5<TET-1> inside the $h r p F$, which could be transferred from the donor bacteria, and (ii) the thuA-F/thuA-R and akr-F/akr-R primer sets (Table 1) to confirm the identity of strain $\mathrm{nE} 1$, which are designed based on the thuA domain-containing protein (TR80_004955) and aldo/keto reductase family oxidoreductase (TR80_015515) genes only existing in strain nE1 but not in the Xcc1-1 and Xcr-R1 strains. The PCR-positive strain nE1 transconjugants were further tested by PCR to determine the existence of pathogenicity island transferred from the donor bacteria.

PCR assays. The PCR primers used in this study are listed in Table 1. The colonies of xanthomonads on the LB agar medium were suspended in $50 \mu \mathrm{l}$ of sterile distilled water. The bacterial suspension was incubated for $10 \mathrm{~min}$ at $100^{\circ} \mathrm{C}$ for cell lysis, and was maintained at $4^{\circ} \mathrm{C}$ before use. The PCR amplification was performed with a Thermal cycler 2720 (Applied Biosystems, Foster City, CA) in a 30- $\mu$ l reaction mixture containing $1 \mu$ of cell lysate, $3 \mu \mathrm{l}$ of primer pair ( 0.35 to $0.5 \mu \mathrm{M}$ of each primer), $15 \mu \mathrm{l}$ of GoTaq green master mix (Promega Corp.), and $11 \mu \mathrm{l}$ of sterile distilled water by using the following program: 1 cycle of denaturation for $1 \mathrm{~min}$ at $94^{\circ} \mathrm{C} ; 35$ cycles consisting of denaturation at $94^{\circ} \mathrm{C}$ for $30 \mathrm{~s}$, annealing at $55^{\circ} \mathrm{C}$ for $30 \mathrm{~s}$, and extension at $72^{\circ} \mathrm{C}$ for $1 \mathrm{~min}$. Reactions were stored at $15^{\circ} \mathrm{C}$ until they were used for analysis. Amplified DNA was detected by electrophoresis in $1.0 \%$ agarose (agarose I, Amresco Inc., Solon, $\mathrm{OH}$ ) in $1 \times$ TAE buffer (40 mM Tris-acetate, $1 \mathrm{mM}$ EDTA, $\mathrm{pH}$ 8.0).

Nucleotide sequence accession number. The 16S rRNA partial sequences of nonpathogenic $X$. campestris strains $\mathrm{nE} 1$ and
nT1 have been assigned GenBank accession numbers KT156666 and KT156667, respectively. The gyrB sequences of those isolates were assigned KT191043 and KT191044, the $h r p G$ were assigned MK858167 and MK858168, and the $h r p X$ were MK878420 and MK878419. The partial sequences of the four housekeeping genes used in the MLSA are MN882614 and MN882615 for dnaK; MN882616 and MN882617 for fyuA; MN882618 and MN882619 for $g y r B$; and MN882620 and MN882621 for $r p o D$. This whole genome shotgun project of $\mathrm{nXan-E} 1$ has been deposited at DDBJ/ EMBL/GenBank under accession number JXYR00000000. The version described in this paper is version JXYR02000000.

\section{RESULTS}

Isolation, characterization, and pathogenicity test of xanthomonads isolated from brassica seeds. The Xan$\mathrm{D}(\mathrm{CCF})$ medium was used to detect the xanthomonads from 50 seed samples ( 30 cabbage, 15 cauliflower, and 5 broccoli seed samples) in 2013 to 2016. The xanthomonad-like bacterial colonies, which were yellow-green, wet-shining, convex and surrounded by milky and clear zones on the medium, were isolated from nine seed samples after incubation for 3 to 4 days at $28^{\circ} \mathrm{C}$. Two characteristic colonies isolated from separate seed samples were subcultured on the YDC medium and also tested by a PCR assay using the estA (Xclip-F2/Xc-lip-R2) primer set. The isolates that were yellow, mucoid and convex on the YDC medium and positive in the estA-PCR were considered xanthomonads (Fig. 1A) (Lee et al. 2009; Wilson et al. 1967). Some seed samples were contaminated with Stenotrophomonas spp., such as S. maltophilia, whose colony is also yellow-

\section{A estA}
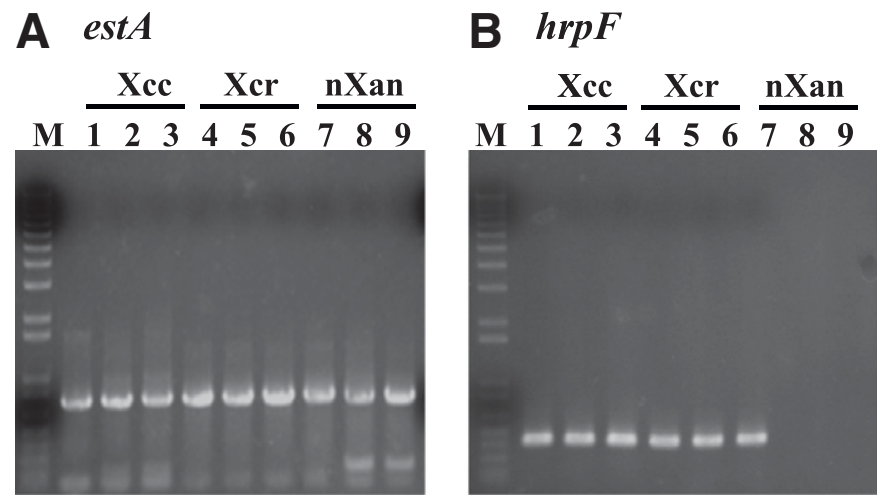

Fig. 1. Polymerase chain reaction analysis of isolated xanthomonads from brassica seeds using the primer sets designed from $\mathbf{A}$, the esterase gene, estA (Xc-lip-F2/Xc-lip-R2; $777 \mathrm{bp}$ ), and $\mathbf{B}$, the pathogenicity island gene, hrpF (hrpF-1-F/hrpF-1-R; 424-bp). Lanes 1 to $3:$ X. campestris pv. campestris (Xcc) strains Xcc1-1, Xcc-G, and Xcc-T1; lanes 4 to 6: X. campestris pv. raphani (Xcr) strains Xcr-X2B1, Xcr-X3A2, and Xcr-TGA; and lanes 7 to 9: nonpathogenic xanthomonad (nXan) strains nE1, nT1, and nA1. M, molecular size marker (1-kb Plus DNA ladder, Invitrogen Life Technologies, Carlsbad, CA).

TABLE 1. Primers used for PCR amplifications

\begin{tabular}{|c|c|c|c|}
\hline Gene & Forward primer $\left(5^{\prime}->3^{\prime}\right)$ & Reverse primer $\left(5^{\prime}->3^{\prime}\right)$ & Product size (bp) \\
\hline$a v r B s 2$ & TGCCGGTGTTGATGCACGA & TCGGTCAGCAGGCTTTC & 850 \\
\hline$h r c R$ & GAAAGGCCCATCGCCATCA & TCACCTCCTACACCAAGAT & 619 \\
\hline$h r p F-1$ & TGTATCGCTATTCCGACTATCTGCC & TTCTTGTAGCCGGTGATCGAGTTGTTC & 424 \\
\hline$h r p F-2$ & ATGTCGCTCAACACGCTTTCTACCGGGAG & TTCTTGTAGCCGGTGATCGAGTTGTTC & 1,906 \\
\hline hrpG & TCGCAGGTCAACGCCAGCCT & GCTCCATGGTGCGGTCGGTG & 544 \\
\hline$T c$ & AGCATCGCCAGTCACTATGGCG & GGCCTGCAACGCGGGCATCC & 849 \\
\hline xорAT & CGAACAGTGTAAATGTGGGG & CGGATACTTCTCTTCTGGGTCG & 325 \\
\hline xор $P$ & GGCGCCGGATACACACAAG & AGCTGCAAACGCTCGGTGA & 954 \\
\hline $\operatorname{thu} A^{\mathrm{a}}$ & CGGATGCTGATCTTCAGCAAGACGGC & GCCGCATAGCGCAGCC & 629 \\
\hline$a k r^{\mathrm{a}}$ & CATCCGCCTCTACCTATGCCCTCG & CGCGGACTGCAGTGGCGAG & 659 \\
\hline
\end{tabular}

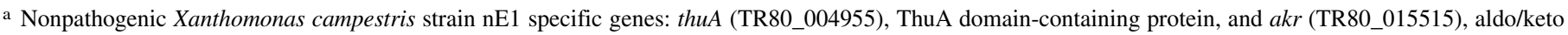
reductase family oxidoreductase. 
green, but nonmucoid on the Xan-D(CCF) medium (Lee et al. 2009). The S. maltophilia isolates are pale or light yellow and flat on the YDC medium and negative in the estA-PCR.

The pathogenicity of isolated xanthomonads was tested by the inoculation test. Some isolates that caused black rot symptoms on cabbage leaves were considered as $X$. campestris pv. campestris, and the isolates causing leaf spot symptoms were $X$. campestris $\mathrm{pv}$. raphani. The other isolates did not cause any visible symptoms and were presumptively considered nonpathogenic xanthomonads. The $X$. campestris pv. campestris and $X$. campestris pv. raphani strains produced a 424-bp DNA fragment in the $h r p F$-PCR reaction using the $h r p F$ primer set (hrpF-1-F/hrpF-1-R). All nonpathogenic xanthomonads tested did not amplify any DNA fragment in the $h r p F$-PCR (Fig. 1B). The two cabbage and two cauliflower seed samples were infested with $X$. campestris pv. campestris, two cabbage seed samples with $X$. campestris pv. raphani, and two cabbage and one broccoli seed samples with nonpathogenic xanthomonads. Each infested seed sample contained only one strain of $X$. campestris pv. campestris, $X$. campestris pv. raphani, and nonpathogenic xanthomonads. The bacterial strains are listed in Table 2.

Further identification and phylogenetic analysis of nonpathogenic xanthomonads. In addition to the characteristic growth features on the Xan-D and YDC media, and the positive reaction in estA-PCR, the nucleotide sequence of $16 \mathrm{~S}$ rRNA was further used to confirm the identity of isolated nonpathogenic xanthomonads. Almost complete nucleotide sequences of $16 \mathrm{~S}$ rRNA of nonpathogenic xanthomonad strains, nE1 and nT1, were determined and compared with the available 16S rRNA sequences in GenBank. The sequences are highly identical (99 to 100\%) to those of X. campestris pv. campestris ATCC 33913 (accession number NR_074936) and X. campestris pv. raphani 756C (CP002789), X. axonopodis pv. citri 306 (NR_074937), and X. oryzae pv. oryzae KACC10331 (NR_074938). Accordingly, the isolated nonpathogenic xanthomonad strains should be assigned to the genus Xanthomonas.

The partial gyrB nucleotide sequence of two nonpathogenic xanthomonad strains was determined and used to construct the phylogenetic tree (Fig. 2). The nonpathogenic xanthomonad strains, $\mathrm{nE} 1$ and nT1, aligned closely with $X$. campestris pv. campestris and $X$. campestris pv. raphani. In addition, the complete $g y r B$ sequences of nE1 and nT1 strains were also determined and shared more than $98 \%$ identity with those of $X$. campestris pv. campestris ATCC 33913 (AE008922) and X. campestris pv. raphani 756C (CP002789), and only 91 to $92 \%$ with other Xanthomonas spp. Therefore, the isolated nonpathogenic xanthomonads should belong to the species $X$. campestris, and are called nonpathogenic $X$. campestris hereafter.

The MLSA analysis showed that $X$. campestris strains from brassica crops formed a monophyletic group, and clearly separated from another group formed by the $X$. arboricola strains isolated from Prunus hosts. Each group was further separated into two subgroups, one with T3SS and the other without the system (Fig. 3). Two isolated nonpathogenic $X$. campestris strains, nE1 and nT1, which are free of T3SS as described below, were grouped together with the T3SS-positive strains of $X$. campestris, but not with T3SSnegative strains of $X$. arboricola. In $X$. campestris group, $X$. campestris pv. barbareae CFBP 5825 is considered nonpathogenic, but it contains T3SS (Roux et al. 2015) and is clustered with the pathogenic and T3SS-positive strains of $X$. campestris,

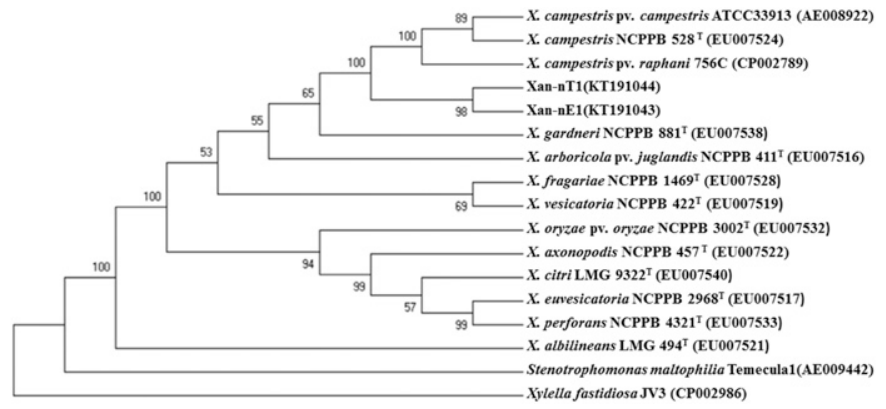

Fig. 2. Unrooted phylogenetic tree derived from neighbor-joining analysis of the partial $\operatorname{gyr} B$ nucleotide sequences of the nonpathogenic xanthomonad strains, $\mathrm{nE1}$ and nT1, isolated from brassica seeds, Xanthomonas spp., and two closely related bacteria, Xylella fastidiosa and Stenotrophomonas maltophilia. Bootstrapping resampling statistics were applied to the tree (1,000 data sets), and bootstrap values are shown on each horizontal branch of the tree. The superscript $\mathrm{T}$ indicates that the strain is the type strain. GenBank accession numbers are given in parentheses after the bacterial names.

TABLE 2. Bacterial strains tested

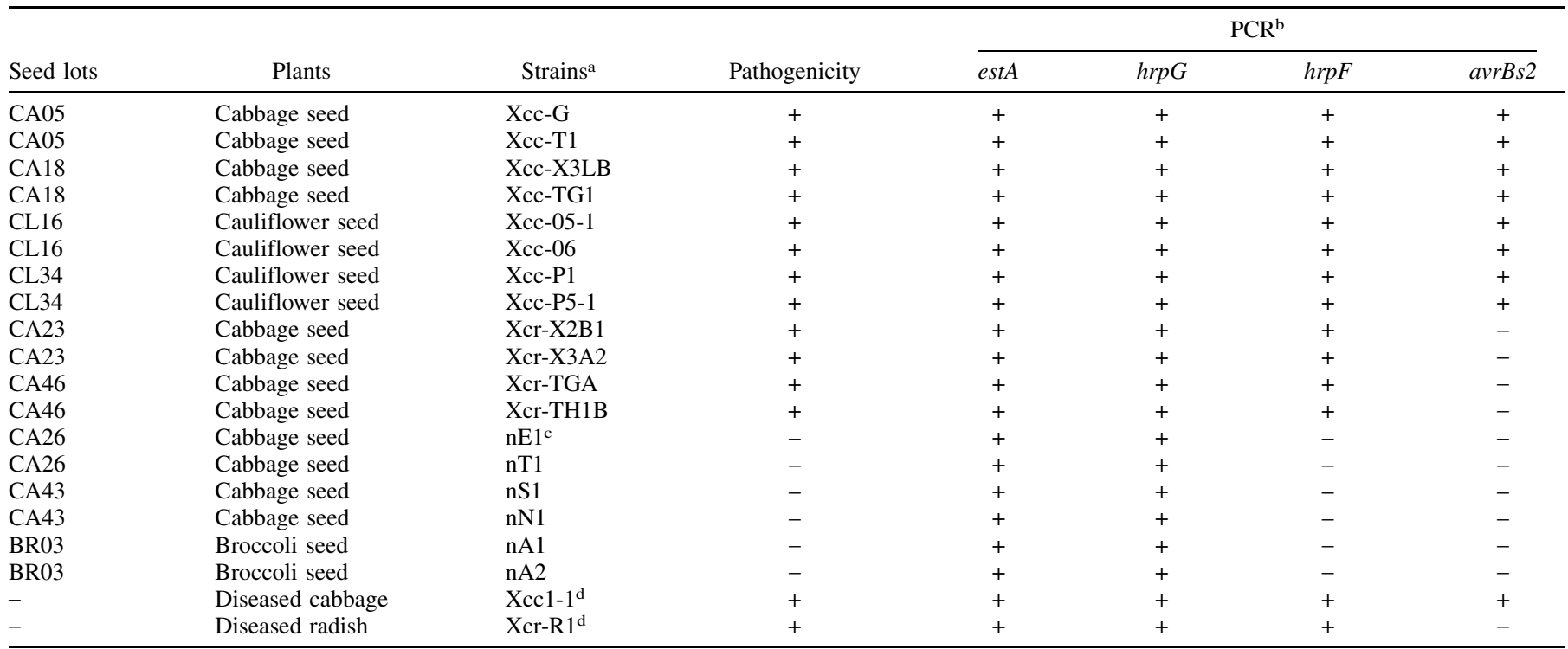

a Xcc and Xcr indicate Xanthomonas campestris pv. campestris and X. campestris pv. raphani, respectively.

${ }^{\mathrm{b}}$ The PCR assays used to differentiate $X$. campestris pv. campestris, $X$. campestris pv. raphanin, and nonpathogenic $X$. campestris as shown in Figures 1 and 6.

$\mathrm{c}$ The $\mathrm{n}$ indicates nonpathogenic for the isolated $X$. campestris strains.

${ }^{\mathrm{d}} X$. campestris pv. campestris Xcc1-1 and X. campestris pv. raphani Xcr-R1 were isolated from diseased cabbage and radish in Taiwan 15 years ago and are considered endemic strains. 
including $X$. campestris pv. campestris, $X$. campestris pv. raphani, and $X$. campestris pv. incanae.

Draft genome analysis of nonpathogenic $X$. campestris strain nE1. Because all isolated nonpathogenic $X$. campestris strains did not amplify any DNA fragment in the $h r p F$-PCR, the lack of pathogenicity might not be attributed only to the absence of $h r p F$. Whole genome sequence of strain $\mathrm{nE} 1$ was determined and analyzed

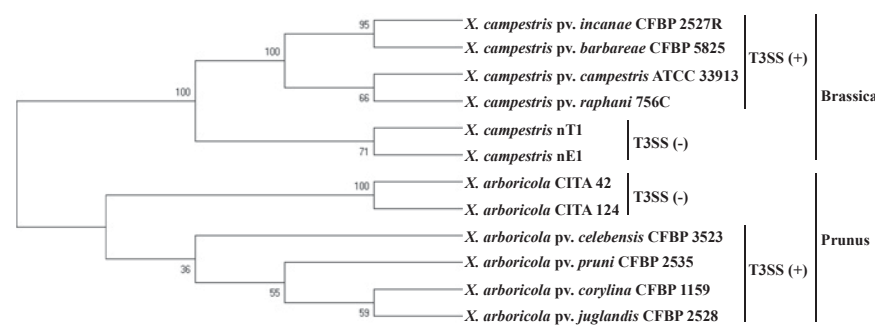

Fig. 3. Phylogenetic tree derived from neighbor-joining analysis of the concatenated sequences of the genes dnaK, fyuA, gyrB, and rpoD of nonpathogenic Xanthomonas campestris strains, nE1 and nT1, isolated in this study and other strains of $X$. campestris isolated from brassica crops and those of $X$. arboricola from prunus. The presence or absence of type III secretion system (T3SS), T3SS (+) or (-), of $X$. campestris pathovars and strains are based on Merda et al. (2017), Roux et al. (2015), and this study, and those of $X$. arboricola are based on Garita-Cambronero et al. (2017). The T3SS (-) strains of $X$. campestris and $X$. arboricola are all nonpathogenic, and the T3SS (+) strains are pathogenic, except $X$. campestris pv. barbareae CFBP 5825, which is considered nonpathogenic but it contains T3SS (Roux et al. 2015). to further understand whether the nonpathogenic $X$. campestris strain also lack other pathogenicity-related genes. The genome sequencing data of strain $\mathrm{nE1}$ are made up of 4.3 million reads of 208-bp average length after quality trim, generating $891-\mathrm{Mb}$ raw data with a $\mathrm{G}+\mathrm{C}$ content of $64 \%$. The raw coverage depth is therefore $178 \times$ over average xanthomonad genome $(5 \mathrm{Mb})$. The reads were assembled into 15 contigs ( $\mathrm{N} 50=242.8 \mathrm{~kb}$ ) with the sum of $5.0 \mathrm{Mb}$. Although the contigs do not overlap each other to form a circular genome of the bacterium, the total length of the contigs is almost close to the genome size of $X$. campestris pv. raphani $756 \mathrm{c}(4.941 \mathrm{Mb})$ and $X$. campestris $\mathrm{pv}$. campestris ATCC 33913 (5.076 Mb).

The contigs of strain $\mathrm{nE} 1$ were mapped to the genome sequences of X. campestris pv. campestris ATCC 33913 (NC_003902) and $X$. campestris pv. raphani $756 \mathrm{c}$ (CP002789). It was found that all contigs of strain nE1 were not aligned to a DNA fragment containing hrp gene cluster (pathogenicity island; T3SS) of either $X$. campestris pv. campestris ATCC 33913 or X. campestris pv. raphani $756 \mathrm{c}$. A 44.5-kb DNA fragment of $X$. campestris pv. campestris ATCC 33913 with pathogenicity island is absent in the strain nE1 (Fig. 4). The DNA fragment of X. campestris pv. campestris ATCC 33913 starts from XCC1208 (glyoxalase family protein) to $\mathrm{XCC} 1247$ (xopP), includes a $23.1-\mathrm{kb}$ pathogenicity island, which is from XCC1217 ( $h r p F)$ to XCC1241 (hpa2), and also contains one putative effector protein gene, $\mathrm{XCC} 1247$ (xopP).

A 59.2-kb DNA fragment of $X$. campestris pv. raphani $756 \mathrm{c}$ strain containing the pathogenicity island does not exist in the strain nE1 (Fig. 4). The DNA fragment begins from XCR_1448 to XCR 1505 (periplasmic beta-glucosidase), covering a $37.8-\mathrm{kb}$ pathogenicity

Xcc ATCC 33913

$44.5 \mathrm{~kb}$

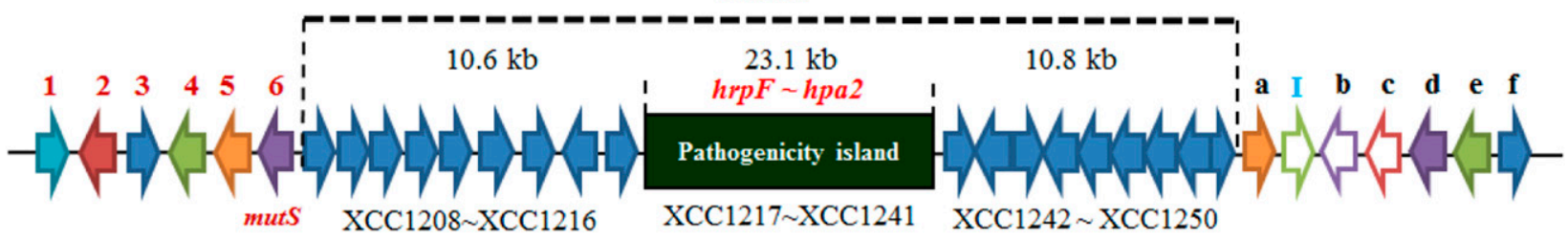

Xcr $756 \mathrm{C}$

$59.2 \mathrm{~kb}$

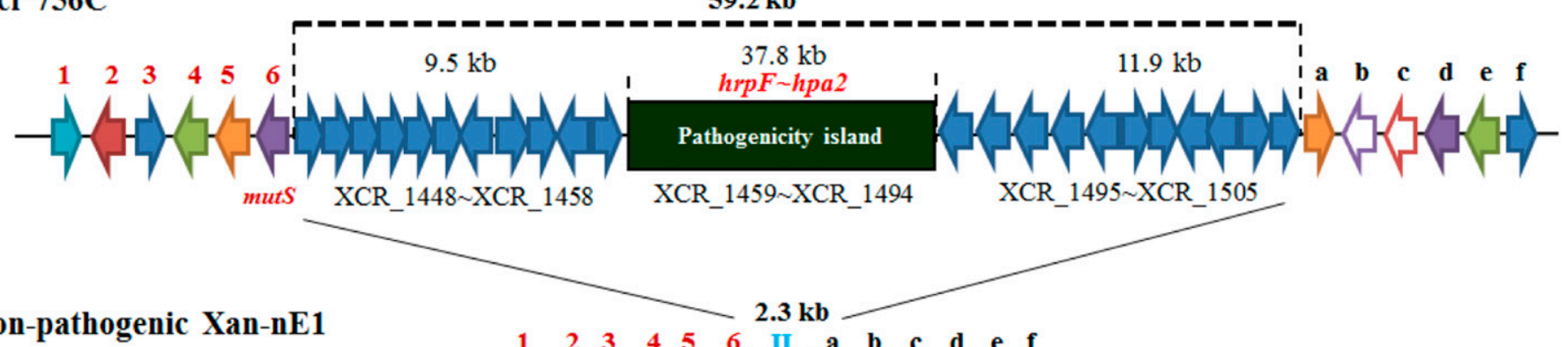

non-pathogenic Xan-nE1

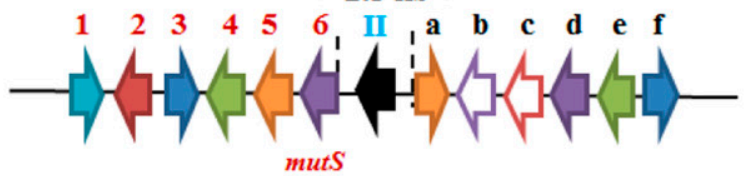

Contig $11(978 \mathrm{~kb})$

Fig. 4. Schematic overview of the comparison of the pathogenicity island (type III secretion system)-containing DNA fragment of Xanthomonas campestris pv. campestris 33913 (Xcc 33913) and X. campestris pv. raphani 756C (Xcr 756c) with the contig 11 of nonpathogenic X. campestris strain nE1 (Xan-nE1). The dashed lines refer to the DNA fragments of X. campestris pv. campestris 33913 and X. campestris pv. raphani $756 \mathrm{c}, 44.5 \mathrm{~kb}$ and $59.2 \mathrm{~kb}$, which are absent in strain $\mathrm{nE} 1$. The pathogenicity island (black bar) from hrpF to hpa2 is $23.1 \mathrm{~kb}$ in X. campestris pv. campestris 33913 and $37.8 \mathrm{~kb}$ in X. campestris pv. raphani $756 \mathrm{c}$. Each arrow indicates the direction of transcription of a protein-coding gene, but its length does not correspond to the actual length of the gene. The genes on the flanking regions of pathogenicity island are indicated as 1 to 6 on the left region, and a to $f$ on the right region. The genes with the same number or letter on the top are the same genes. For example, gene 6 refers to XCC1207, XCR_1446, and TR80_011000, which are all mutS (DNA mismatch repair protein), and the gene a refers to XCC1251, XCR_1506, and TR80_011015, which are the alpha-L-fucosidase (F5-8 type C domain protein) genes. The gene I and II indicate the genes present only in the X. campestris pv. campestris 33913 or strain $\mathrm{nE} 1$, respectively. The gene $\mathrm{I}$ of X. campestris pv. campestris 33913 is IS1478, and the gene II of strain $\mathrm{nE} 1$ is a chemotaxis protein gene (TR80_011005). 
island, which is from XCR_1459 ( $h r p F)$ to XCR_1494 (hpa2), and also consists of five putative effector protein genes, XCR_1464 (xopAD), XCR_1464a (xopAT), XCR_1492 (xopA), XCR_1499 (xopAL1), and XCR_1500 (xopP).

The contig $11(978 \mathrm{~kb})$ of the strain $\mathrm{nE} 1 \mathrm{can}$ be mapped to the genes in the flanking regions of the above DNA fragment of X. campestris pv. campestris ATCC 33913 or X. campestris pv. raphani strain $756 \mathrm{c}$. The contig contains the genes mutS (TR80_ 011000), corresponding to XCC1207 and XCR_1446, in the right border, and alpha-L-fucosidase (TR80_011005), similar to XCC1251 and XCR_1506, in the left border of the DNA fragments shown in Figure 4.

The absence of entire T3SS of strain $\mathrm{nE} 1$ is the reason why the strain did not amplify any DNA fragment in the $h r p F$-PCR. Besides, the assembled contigs of the strain $\mathrm{nE} 1$ contain none of 13 type III effector genes currently identified in X. campestris pv. campestris or X. campestris pv. raphani (Ryan et al. 2011; White et al. 2009), which include nine type III core effector genes, avrBs2 (XCC0052), xopN (XCC0231), xopR (XCC0258,XCR_4254), xopX (XCC0529-0530), xopQ $\left(\mathrm{XCC1072),xopP(XCC1247,XCR \_ 1500),} \mathrm{xopZ(XCC1975),} \mathrm{xорK}\right.$ (XCC2899), and xopL (XCC4186), and four variable effector genes, xopF1(XCC1218, XCR_1470), xорE2 (XCC1629), хорАH (XCC2109), and xopD (XCC2896). The X. campestris pv. campestris ATCC 33919 strain contains all of 13 effector genes, and $X$. campestris pv. raphani $756 \mathrm{c}$ strain has only three of them (xopR, xopP, and xopF1) (Ryan et al. 2011).

Although the strain $\mathrm{nE} 1$ does not contain the hrp gene cluster (pathogenicity island) and type III effector genes, the strains have the homologs of two transcriptional activator genes of pathogenicity island, $h r p G$ and $h r p X$ (both in the contig 9). Both $h r p G$ and $h r p X$ of strain nE1 share 96 to $97 \%$ identity with those of $X$. campestris pv. campestris ATCC 33913 and $X$. campestris pv. raphani 756c, but only have 77 to $85 \%$ identity with other species of Xanthomonas, such as $X$. axonopodis pv. manihotis, $X$. vesicatoria, $X$. oryzae $\mathrm{pv}$. oryzae, and $X$. citri. The results further confirmed that the strain $\mathrm{nE1}$ is indeed closely related to $X$. campestris pv. campestris and $X$. campestris pv. raphani.

PCR differentiation of $X$. campestris pv. campestris, $X$. campestris pv. raphani, and nonpathogenic $X$. campestris isolated from brassica seeds. Based on the above genome analyses, some genes can be utilized to design the primers to differentiate $X$. campestris pv. campestris, X. campestris $\mathrm{pv}$. raphani, and nonpathogenic $X$. campestris by the PCR assay after the isolation of xanthomonads from brassica seeds by the Xan-D medium. Two transcription regulator genes, $h r p G$ and $h r p X$, exist in all $X$. campestris pv. campestris, $X$. campestris pv. raphani, and nonpathogenic $X$. campestris strains, and the $h r p G$-PCR can be used to preliminarily determine whether the isolates belong to $X$. campestris

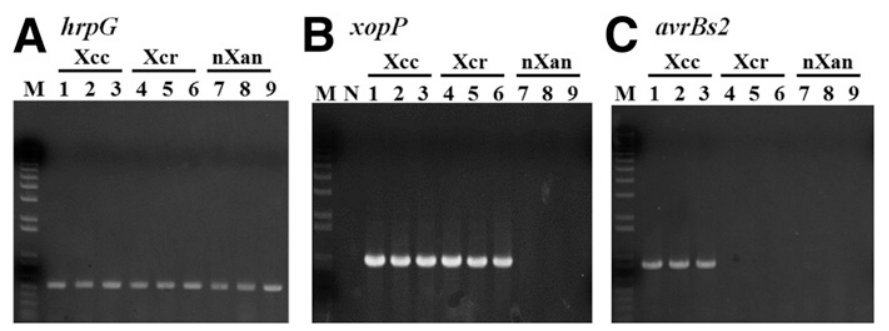

Fig. 5. Differentiation of Xanthomonas campestris pv. campestris (Xcc), X. campestris pv. raphani (Xcr), and nonpathogenic $X$. campestris (nXan) strains by the PCR assay and agarose gel electrophoresis using the primer sets designed from A, the transcriptional regulator, hrpG (hrpG-F1/hrpG-R; 544 $\mathrm{bp}$ ), and the type III effector genes, B, xopP (xopP-F/xop-R; 954 bp) and C, avrBs2 (avrBs2-F/avrBs2-R; 850 bp). Lanes 1 to 3: X. campestris pv. campestris strains Xcc1-1, Xcc-G, and Xcc-T1; lanes 4 to 6: X. campestris pv. raphani strains Xcr-X2B1, Xcr-X3A2, and Xcr-TGA; and lanes 7 to 9: nonpathogenic $X$. campestris strains $\mathrm{nE1}$, nT1, and nA1. M, molecular size marker (1-kb Plus DNA ladder, Invitrogen Life Technologies, Carlsbad, CA).
(Fig. 5A). The genes in the pathogenicity island, such as $h r p F$, are present in all $X$. campestris pv. campestris and $X$. campestris pv. raphani but not in the nonpathogenic $X$. campestris. The hrpF-PCR was employed to differentiate the pathogenic $X$. campestris pv. campestris and $X$. campestris pv. raphani from nonpathogenic $X$. campestris as in Figure 1B. As for the type III effector protein genes, $X$. campestris pv. campestris has more type III effector protein genes than $X$. campestris pv. raphani, and nonpathogenic $X$. campestris lack all of them. For example, xopP exists in both $X$. campestris pv. campestris and $X$. campestris pv. raphani, but the avrBs 2 is present only in $X$. campestris pv. campestris but not in $X$. campestris pv. raphani, which can be used to distinguish between $X$. campestris $\mathrm{pv}$. campestris and $X$. campestris pv. raphani (Fig. 5B and C).

Selection of transconjugants and transfer of pathogenicity island. To determine whether the nonpathogenic $X$. campestris strain $\mathrm{nE} 1$ from the seeds can acquire the pathogenicity island from the endemic $X$. campestris pv. campestris or X. campestris pv. raphani, conjugation tests were undertaken. The identity of selected transconjugants of strain $\mathrm{nE} 1\left(\mathrm{Rif}^{\mathrm{R}}, \mathrm{Tc}^{\mathrm{R}}\right)$ was determined by PCR using the primer sets designed from the tetracycline resistance $\left(\mathrm{Tc}^{\mathrm{R}}\right)$ gene of Tn5<TET-1> inside the $h r p F$ of pathogenicity island in two donor bacteria, and two specific gene markers of strain $\mathrm{nE1}$, thuA domain-containing protein (TR80_004955) and aldo/keto reductase family oxidoreductase (TR80_015515) genes (Fig. 6). The PCR-positive colonies were considered transconjugants of strain $\mathrm{nE1}$. The strain $\mathrm{nE1}-\mathrm{MC} 1\left(\mathrm{Rif}^{\mathrm{R}}, \mathrm{Tc}^{\mathrm{R}}\right)$ transconjugant was selected from the mating between strain $\mathrm{nE1}\left(\mathrm{Rif}^{\mathrm{R}}\right)$ and Xcc1-1 (hrpF:: Tn5<TET-1>), and the $n E 1-M R 1\left(\operatorname{Rif}^{R}, \mathrm{Tc}^{\mathrm{R}}\right)$ transconjugant from the mating between the $\mathrm{nE} 1\left(\mathrm{Rif}^{\mathrm{R}}\right)$ and Xcr-R1 (hrpF::Tn5<TET-1>).

Both nE1-MC1 (Rif $\left.{ }^{\mathrm{R}}, \mathrm{Tc}^{\mathrm{R}}\right)$ and $\mathrm{nE1}$-MR1(Rif $\left.{ }^{\mathrm{R}}, \mathrm{Tc}^{\mathrm{R}}\right)$ transconjugants acquired the $h r p F:$ Tn5<TET-1> marker along with the pathogenicity island from Xcc1-1 ( $h r p F:: T n 5<$ TET-1>) and XcrR1 (hrpF::Tn5<TET-1>) donor bacteria. The existence of pathogenicity island was determined by PCR assays using primer sets designed from the genes of pathogenicity island, such as $h r c C, h r c J$, $h r c Q$, and $h r c R$. Two genes, xopAT and $x o p A D$, only existing in the pathogenicity island of $X$. campestris pv. raphani, could be detected by the PCR assays only in nE1-MR1 $\left(\mathrm{Rif}^{\mathrm{R}}, \mathrm{Tc}^{\mathrm{R}}\right.$ ) but not in $\mathrm{nE} 1-$ $\mathrm{MC1}\left(\mathrm{Rif}^{\mathrm{R}}, \mathrm{Tc}^{\mathrm{R}}\right)$ transconjugants. However, the type III effector protein genes outside the pathogenicity island, such as $x o p D$ and
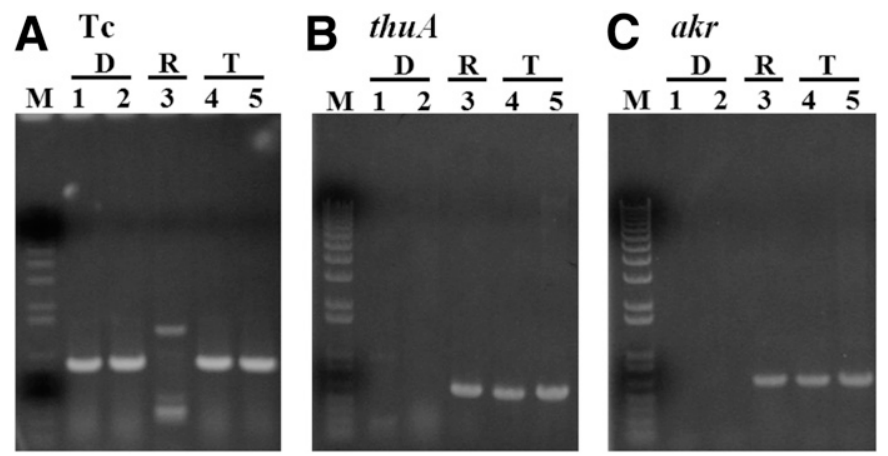

Fig. 6. Determination of the identity of two transconjugants ( $T$ ) of nonpathogenic Xanthomonas campestris strain $\mathrm{nE} 1$ selected from the conjugations between the pathogenic donor bacteria (D), X. campestris pv. campestris and $X$. campestris pv. raphani, and recipient bacterium $(\mathrm{R})$, strain $\mathrm{nE} 1$ by the PCR assay and agarose gel electrophoresis using the primer sets designed from $\mathbf{A}$, tetracycline resistance gene (Tc-F/Tc-R; 849-bp) of Tn5<TET-1 $>$ inside the $h r p F$ of two donor bacteria, and two specific gene markers of strain $\mathrm{nE} 1, \mathbf{B}$, thuA (TR80_004955), thuA domain-containing protein gene (thuA-F/thuA-R; 629-bp), and C, akr (TR80_015515), aldo/keto reductase family oxidoreductase gene (akr-F/akr-R; 659-bp). Lanes 1 and 2: the donor bacteria (D), $X$. campestris pv. campestris Xcc1-1 (hrpF::Tn5<TET-1>) and X. campestris pv. raphani Xcr-R1 (hrpF::Tn5<TET-1>); lane 3: the recipient bacterium (R), strain nE1 (Rif ${ }^{\mathrm{R}}$ ); and lanes 4 and 5: the transconjugants (T), nE1-MC1 (Rif ${ }^{\mathrm{R}}$, $\mathrm{Tc}^{\mathrm{R}}$ ) and $\mathrm{nE1}$-MR1 ( Rif $\left.^{\mathrm{R}}, \mathrm{Tc}^{\mathrm{R}}\right)$. M, molecular size marker (1-kb Plus DNA ladder, Invitrogen Life Technologies, Carlsbad, CA). 
avrBs2, were not detected in both transconjugants by PCR assays. The representative PCR results are shown in Figure 7. Even though nE1-MC1 (Rif $\left.{ }^{\mathrm{R}}, \mathrm{Tc}^{\mathrm{R}}\right)$ and $\mathrm{nE1-MR}$ ( $\left.\mathrm{Rif}^{\mathrm{R}}, \mathrm{Tc}^{\mathrm{R}}\right)$ transconjugants acquired the pathogenicity island in which $h r p F$ is knocked out, no type III effector gene was cotransferred.

\section{DISCUSSION}

This study provides the first experimental results indicating that brassica vegetable seeds, such as cabbage and cauliflower, could be infested with nonpathogenic $X$. campestris, $X$. campestris pv. campestris, or $X$. campestris pv. raphani, which cannot be distinguished by any semiselective media, such as the Xan-D medium. If nonpathogenic $X$. campestris cannot be differentiated from real pathogens, seed lots may be unnecessarily rejected or subjected to control treatments. The genomic and phylogenetic analyses in this study reveal that T3SS genes are important and useful genetic markers to differentiate nonpathogenic and pathogenic strains of $X$. campestris, which can be used to improve detection methods in the brassica seed health management.

Nonpathogenic xanthomonads have been isolated before from bean debris (Gilbertson et al. 1990), apple (Maas et al. 1985), tomato and pepper transplants (Gitaitis et al. 1987), rice seed lots (Ming et al. 1991), and Prunus spp. (Garita-Cambronero et al. 2017), and most nonpathogenic xanthomonads belong to $X$. arboricola and are not closely related to the pathovars of the plant from which they were isolated (Vauterin et al. 1996). In this study, X. arboricola was not found and the pathogenic and nonpathogenic xanthomonads isolated from the brassica seeds were all X. campestris. The nonpathogenic $X$. campestris were not assigned to any pathovar, because they are not pathogenic and the criterion of pathovar identification is based on host pathogenicity. Although nonpathogenic $X$. campestris, $X$. campestris pv. campestris, and $X$. campestris pv. raphani are closely related, they were not yet co-isolated from the same brassica seed lot in this study. It is possible that the number of nonpathogenic $X$. campestris overwhelmed those of pathogenic $X$. campestris on seed surface or vice versa, or that the examined colony number was not big enough to distinguish them. Alternatively, the closely related nonpathogenic and pathogenic $X$. campestris might compete with each other for the seeds (or even flowers and seed pots) as niches for survival. Therefore, it would be of interest to test whether the nonpathogenic xanthomonads could be used as a biological control agent to exclude $X$. campestris pv. campestris and $X$. campestris pv. raphani from brassica seeds and cause less disease incidence and severity during cultivation.

The MLSA analysis showed that the $X$. campestris and $X$. arboricola strains are first separated into two groups based on plant hosts, and each group was further divided into two subgroups according to the presence or absence of T3SS. The analysis provides the evolutionary sequence about the acquisition of pathogenicity in Xanthomonas. The nonpathogenic $X$. campestris strains isolated from brassica crops lack not only T3SS but also all type III effector genes and should be considered commensal bacteria, which have been first adapted to the brassica cultivation system, and inherit the capacities for epiphytic colonization on the hosts and saprophytic survival on the debris after harvest (Merda et al. 2017). The T3SS and type III effector genes may not be needed for them to live and multiply essentially in a dead-cell environment. Even the sugarcane pathogen $X$. albilineans, which lives in xylem (dead cells) limited lifestyle, also does not possess all genes for T3SS and any of the known type III effector genes (Pieretti et al. 2009).

As commensal bacteria, the nonpathogenic $X$. campestris strains contain two transcriptional activator genes, $h r p G$ and $h r p X$, which also exist in pathogenic $X$. campestris pv. campestris and $X$. campestris pv. raphani. HrpG regulates the expression of hrpX, and HrpX can turn on genes especially for plant cell wall degradation, amino acid biosynthesis, and sugar and iron transport
(Wang et al. 2008). The genes for plant cell wall degradation include polygalacturonase, protease, and lipase genes, which belong to the HrpX regulon and are required for both pathogenic and saprophytic life processes. It is possible that whenever nonpathogenic or pathogenic $X$. campestris contacts plant tissue (dead or living), $h r p G$ and $h r p X$ could be induced to activate the genes for plant cell wall degradation, allowing the nonpathogenic $X$. campestris to obtain the nutrients from plant tissue surfaces or debris, or making the pathogenic $X$. campestris pv. campestris and $X$. campestris pv. raphani get access to the cell membranes of living cells. HrpX also activates the T3SS and type III effector genes in the pathogenic $X$. campestris pv. campestris and $X$. campestris pv. raphani in order to overcome the plant defense responses and cause the symptoms in the susceptible plant hosts (Huang et al. 2009; Wengelnik and Bonas 1996; Wengelnik et al. 1996).

All tested nonpathogenic $X$. campestris were negative in the hrpF-PCR and pathogenic $X$. campestris pv. campestris and $X$. campestris pv. raphani strains are all positive. The hrp genes have been used before to develop a PCR-based detection method to differentiate the pathogenic $X$. campestris pv. vesicatoria and $X$. campestris pv. campestris from nonpathogenic xanthomonads (Leite et al. 1994; Park et al. 2004). In this study, we provide direct genomic evidence that the negative result in the $h r p F$-PCR is attributed to the lack of the entire pathogenicity island (T3SS) in nonpathogenic $X$. campestris. Nonpathogenic $X$. campestris may acquire the pathogenicity island through horizontal gene transfer when the bacterium colonizes the same niche with pathogenic bacteria. Nonpathogenic $X$. campestris strain nE1 was demonstrated to be able to acquire the pathogenicity island by conjugation with two endemic brassica pathogens, Xcc1-1 and Xcr-R1, which were isolated from the diseased cabbage and radish in Taiwan. In a natural niche, it has been found that the chromosomal hrp or copper resistance genes could be indeed transferred by conjugation among pathogenic strains of $X$. axonopodis pv. vesicatoria (Basim et al. 1999). Therefore, it is possible that the nonpathogenic $X$. campestris from the imported seeds may have a chance to colonize the same niche with the endemic $X$. campestris pv. campestris or $X$. campestris pv. raphani in the brassica cultivation area, and the genetic material exchanges may take place between them to allow

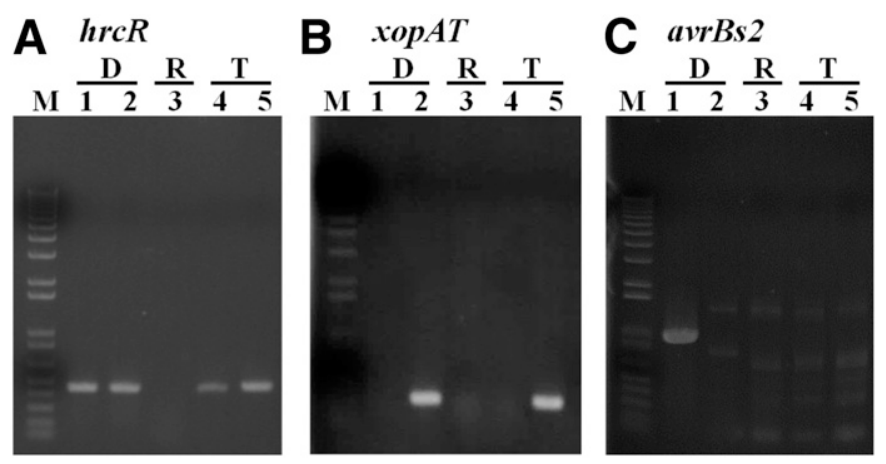

Fig. 7. Determination of the existence of pathogenicity island (PI; type III secretion system) and type III effector genes in two transconjugants (T) of nonpathogenic Xanthomonas campestris strain nE1 selected from the conjugations between the pathogenic donor bacteria (D), X. campestris pv. campestris and $X$. campestris pv. raphani, and recipient bacterium (R), strain $\mathrm{nE} 1$ by the PCR assay and agarose gel electrophoresis using the primer sets designed from A, $h r c R$ (hrcR-F+ hrcR-R; 463-bp), a gene of PI existing in $X$. campestris pv. campestris and $X$. campestris pv. raphani, B, xopAT (xopATF+xopAT-R; 325-bp), a gene of PI existing only in $X$. campestris pv. raphani, and $\mathbf{C}$, avrBs2 (avrBs2-F/avrBs2-R; 850-bp), a type III effector gene existing only in the $X$. campestris pv. campestris. Lanes 1 and 2: the donor bacteria (D), $X$. campestris pv. campestris Xcc1-1 (hrpF::Tn5<TET-1>) and X. campestris pv. raphani Xcr-R1 (hrpF::Tn5<TET-1>); lane 3: the recipient bacterium (R), strain nE1 $\left(\mathrm{Rif}^{\mathrm{R}}\right)$; and lanes 4 and 5: the transconjugants (T) nE1-MC1 (Rif ${ }^{\mathrm{R}}$, $\mathrm{Tc}^{\mathrm{R}}$ ) and $\mathrm{nE1-MR} 1\left(\mathrm{Rif}^{\mathrm{R}}, \mathrm{Tc}^{\mathrm{R}}\right)$. M, molecular size marker (1-kb Plus DNA ladder, Invitrogen Life Technologies, Carlsbad, CA). 
the nonpathogenic $X$. campestris to acquire the T3SS genes. Furthermore, type III effector genes are acquired afterward through additional gene transfers and accumulated stepwise in the nonpathogenic $X$. campestris as a consequence of differential adaptation to brassica host cultivars (Merda et al. 2017). It is also highly possible that the nonpathogenic $X$. campestris might transfer genes to $X$. campestris pv. campestris or $X$. campestris pv. raphani to enhance their survival capacities on the dead brassica leaves and/or on the seeds. Therefore, it cannot be ignored that nonpathogenic $X$. campestris on seeds could be a potential gene resource for horizontal gene transfer to cause the genetic diversity of the endemic pathogenic $X$. campestris pv. campestris and $X$. campestris pv. raphani strains.

\section{ACKNOWLEDGMENTS}

We thank Ya-Chun Chang (Department of Plant Pathology, National Taiwan University, Taipei, Taiwan) for helpful discussions and critical reading of the manuscript.

\section{LITERATURE CITED}

Basim, H., Stall, R. E., Minsavage, G. V., and Jones, J. B. 1999. Chromosomal gene transfer by conjugation in the plant pathogen Xanthomonas axonopodis pv. vesicatoria. Phytopathology 89:1044-1049.

Berg, T., Tesoriero, L., and Hailstones, D. L. 2005. PCR-based detection of Xanthomonas campestris pathovars in Brassica seed. Plant Pathol. 54: 416-427.

Daniels, M. J., Barber, C. E., Turner, D. C., Cleary, W. G., and Sawzyc, M. K. 1984. Isolation of mutants of Xanthomonas campestris pv. campestris showing altered pathogenicity. J. Gen. Microbiol. 130:2447-2455.

Fargier, E., Fischer-Le Saux, M., and Manceau, C. 2011. A multilocus sequence analysis of Xanthomonas campestris reveals a complex structure within crucifer-attacking pathovars of this species. Syst. Appl. Microbiol. 34:156-165.

Fargier, E., and Manceau, C. 2007. Pathogenicity assays restrict the Xanthomonas campestris into three pathovars and reveal nine races within X. campestris pv. campestris. Plant Pathol. 56:805-818.

Garita-Cambronero, J., Palacio-Bielsa, A., López, M. M., and Cubero, J. 2017. Pan-genomic analysis permits differentiation of virulent and non-virulent strains of Xanthomonas arboricola that cohabit Prunus spp. and elucidate bacterial virulence factors. Front. Microbiol. 8:573.

Gilbertson, R. L., Rand, R. E., and Hagedorn, D. J. 1990. Survival of Xanthomonas campestris pv. phaseoli and pectolytic strains of Xanthomonas campestris in bean debris. Plant Dis. 74:322-327.

Gitaitis, R. D., Sasser, M. J., Beaver, R. W., Mclnnes, T. B., and Stall, R. E. 1987. Pectolytic xanthomonads in mixed infections with Pseudomonas syringae pv. syringae, P. syringae pv. tomato, and Xanthomonas campestris pv. vesicatoria in tomato and pepper transplants. Phytopathology 77:611-615.

Huang, D. L., Tang, D. J., Liao, Q., Li, X. Q., He, Y. Q., Feng, J. X., Jiang, B. L., Lu, G. T., and Tang, J. L. 2009. The Zur of Xanthomonas campestris is involved in hypersensitive response and positively regulates the expression of the $h r p$ cluster via $h r p X$ but not $h r p G$. Mol. Plant-Microbe Interact. 22:321-329.

Lee, Y.-A., Sung, A.-N., Liu, T.-F., and Lee, Y.-S. 2009. Combination of a chromogenic differential medium and estA-specific PCR for the isolation and detection of phytopathogenic Xanthomonas spp. Appl. Environ. Microbiol. 75:6831-6838.

Leite, R. P., Jr., Minsavage, G. V., Bonas, U., and Stall, R. E. 1994. Detection and identification of phytopathogenic Xanthomonas strains by amplification of DNA sequences related to the hrp Genes of Xanthomonas campestris pv. vesicatoria. Appl. Environ. Microbiol. 60:1068-1077.

Maas, J. L., Finney, M. M., Civerolo, E. L., and Sasser, M. 1985. Association of an unusual strain of Xanthomonas campestris with apple. Phytopathology $75: 438-445$.

Merda, D., Briand, M., Bosis, E., Rousseau, C., Portier, P., Barret, M., Jacques, M.-A., and Fischer-Le Saux, M. 2017. Ancestral acquisitions, gene flow and multiple evolutionary trajectories of the type three secretion system and effectors in Xanthomonas plant pathogens. Mol. Ecol. 26:5939-5952.

Miller, J. H. 1972. Experiments in Molecular Genetics. Cold Spring Harbor Laboratory, Cold Spring Harbor, New York.

Ming, D., Ye, H., Schaad, N. W., and Roth, D. A. 1991. Selective recovery of Xanthomonas spp. from rice seed. Phytopathology 81:1358-1363.

Park, Y. J., Lee, B. M., Ho-Hahn, J., Lee, G. B., and Park, D. S. 2004. Sensitive and specific detection of Xanthomonas campestris pv. campestris by PCR using species-specific primers based on hrpF gene sequences. Microbiol. Res. 159:419-423.

Parkinson, N., Aritua, V., Heeney, J., Cowie, C., Bew, J., and Stead, D. 2007. Phylogenetic analysis of Xanthomonas species by comparison of partial gyrase B gene sequences. Int. J. Syst. Evol. Microbiol. 57: 2881-2887.

Pieretti, I., Royer, M., Barbe, V., Carrere, S., Koebnik, R., Cociancich, S., Couloux, A., Darrasse, A., Gouzy, J., Jacques, M., Lauber, E., Manceau, C., Mangenot, S., Poussier, S., Segurens, B., Szurek, B., Verdier, V., Arlat, M., and Rott, P. 2009. The complete genome sequence of Xanthomonas albilineans provides new insights into the reductive genome evolution of the xylem-limited Xanthomonadaceae. BMC Genomics 10:616.

Roberts, S. J., Hiltunen, L. H., Hunter, P. J., and Brough, J. 1999. Transmission from seed to seedling and secondary spread of Xanthomonas campestris pv. campestris in Brassica transplants: Effects of dose and watering regime. Eur. J. Plant Pathol. 105:879-889.

Roux, B., Bolot, S., Guy, E., Denancé, N., Lautier, M., Jardinaud, M. F., Saux, M. F. L., Portier, P., Jacques, M. A., Gagnevin, L., Pruvost, O., Lauber, E., Arlat, M., Carrere, S., Koebnik, R., and Noel, L. D. 2015. Genomics and transcriptomics of Xanthomonas campestris species challenge the concept of core type III effectome. BMC Genomics 16:975.

Ryan, R. P., Vorhoiter, F.-J., Potnis, N., Jones, J. B., Van Siuys, M.-A., Bogdanove, A. J., and Dow, J. M. 2011. Pathogenomics of Xanthomonas: Understanding bacterium-plant interactions. Nat. Rev. Microbiol. 9: 344-355.

Saitou, N., and Nei, M. 1987. The neighbor-joining method: A new method for reconstructing phylogenetic trees. Mol. Biol. Evol. 4:406-425.

Schaad, N. W., and Franken, A. A. J. M. 1996. ISTA handbook on seed health testing. Working Sheet No. 50 (2nd ed): Xanthomonas campestris pv. campestris. ISTA, Zurich, Switzerland.

Tamura, K., Dudley, J., Nei, M., and Kumar, S. 2007. MEGA4: Molecular Evolutionary Genetics Analysis (MEGA) software version 4.0. Mol. Biol. Evol. 24:1596-1599.

Thompson, J. D., Higgins, D. G., and Gibson, T. J. 1994. CLUSTAL W: Improving the sensitivity of progressive multiple sequence alignment through sequence weighting, position-specific gap penalties and weight matrix choice. Nucleic Acids Res. 22:4673-4680.

Vauterin, L., Yang, P., Alvarez, A., Takikawa, Y., Roth, D. A., Vidaver, A. K., Stall, R. E., Kersters, K., and Swings, J. 1996. Identification of non-pathogenic Xanthomonas strains associated with plants. Syst. Appl. Microbiol. 19:96-105.

Wang, L., Rong, W., and He, C. 2008. Two Xanthomonas extracellular polygalacturonases, PghAxc and PghBxc, are regulated by type III secretion regulators $\mathrm{HrpX}$ and $\mathrm{HrpG}$ and are required for virulence. Mol. PlantMicrobe Interact. 21:555-563.

Wengelnik, K., and Bonas, U. 1996. HrpXv, an AraC-type regulator, activates expression of five of the six loci in the hrp cluster of Xanthomonas campestris pv. vesicatoria. J. Bacteriol. 178:3462-3469.

Wengelnik, K., Van den Ackerveken, G., and Bonas, U. 1996. HrpG, a key hrp regulatory protein of Xanthomonas campestris pv. vesicatoria is homologous to two-component response regulators. Mol. Plant-Microbe Interact. 9: 704-712.

White, F. F., Potnis, N., Jones, J. B., and Koebnik, R. 2009. The type III effectors of Xanthomonas. Mol. Plant Pathol. 10:749-766.

Wilson, E. E., Zeitoun, F. M., and Fredrickson, D. L. 1967. Bacterial phloem canker, a new disease of Persian walnut trees. Phytopathology 57:618-621.

Yang, M.-K., Su, W.-C., and Kuo, T.-T. 1991. Highly efficient transfection of Xanthomonas campestris by electroporation. Bot. Bull. Acad. Sin. 32: 197-203.

Young, J. M., Park, D.-C., Shearman, H. M., and Fargier, E. 2008. A multilocus sequence analysis of the genus Xanthomonas. Syst. Appl. Microbiol. $31: 366-377$ 